\title{
Gel Filtration of the Hemolymph of the Honey Bee (Apis mellifera L.)
}

Adult worker honey bees (Apis mellifera L.) produced agglutinating substances in response to an injection of a vaccine prepared from Bacillus lavvae White ${ }^{1}$. Since these substances are expected to be protein, one step in their clarification is an investigation of the proteins in bee hemolymph. Separation of hemolymph protein by poly acrylamide gel disc electrophoresis recently showed that the hemolymph of adult worker honey bees contains 9 protein bands which remain unchanged in the adult regardless of the age or diet of the insect ${ }^{2}$.

The present investigation was therefore made at the Tucson Bee Research Laboratory in 1968 to estimate the molecular weights of the proteins in honey bee hemolymph by gel filtration on Sephadex G-200 with rabbit hemolysin as a standard. I selected rabbit hemolysin as the mammalian serum because rabbit antibody to sheep erythrocytes has a sedimentation constant of 18 to $19^{3,4}$. Thus, hemolysin contains all types of serum globulins and albumin.

Sephadex ${ }^{\circledR 5}$ is a modified dextran which separates components of a mixture on the basis of their molecular size. Sephadex G-200 has been used to fractionate mammalian serum proteins ${ }^{6}$ and has a fractionation range of 5,000 to $800,000 \mathrm{~mol}$ weight $(\mathrm{Mw})$ for peptides and globular proteins ${ }^{7}$. The largest globulin, $\operatorname{IgM}(\mathrm{Mw} \simeq 900,000)^{8}$, appears in the effluent as the first component. Other smaller globulins follow, including IgG ( $\gamma$-globulin), which has a $\mathrm{Mw}$ of about $160,000^{\circ}$. Albumin, which has the lowest $\mathrm{Mw}$ $(68,000)$ of the major serum components ${ }^{10}$, is the last component to leave the column.

Hemolymph of adult worker honey bees was collected from the thorax as previously described". Rabbit antiserum against sheep erythrocytes (hemolysin) was prepared by the method of CAmpBell et al.11 using the i.v. route; the titer of this serum was 4000 .

A $2 \times 20$-cm glass chromatographic column was packed with Sephadex G-200 supported by glass wool and a thin layer of Sephadex G-25. Swelling of the Sephadex G-200 beads was accomplished with $0.1 M$ tris- $\mathrm{HCl}$ buffer, $\mathrm{pH} 8.0$, and $0.2 M \mathrm{NaCl}$ for 3 days. Then $1 \mathrm{ml}$ of the hemolymph or hemolysin was layered on the column for fractionation. The separation was carried out at $22^{\circ} \mathrm{C}$ using the buffer and $0.2 M \mathrm{NaCl}$ with a flow rate of $10-20 \mathrm{ml} / \mathrm{h}$. The fraction volume was $5 \mathrm{ml}$. The protein concentration was estimated by measuring the optical density (OD) of the samples at $280 \mathrm{~nm}$.

The figure shows the results of the fractionation of hemolysin and honey bee hemolymph. Rabbit hemolysin contained a large amount of 19S IgM (1st peak), a 7S IgG peak (2nd peak), and a 3rd peak containing albumin. The $19 \mathrm{~S}$ hemolysin peak again gave a titer of 4000 . No other peaks contained antibody to sheep erythrocytes. Honey bee hemolymph contained 2 large fractions, a peak in the 19S.region and another peak between the $19 \mathrm{~S}$ and $7 \mathrm{~S}$ region of hemolysin.

Thus, bee hemolymph contains a large fraction which has a Mw simjlar to that of $19 \mathrm{~S} \mathrm{IgM} \mathrm{in} \mathrm{hemolysin.} \mathrm{A} \mathrm{2nd}$ peak of unknown Mw was found between the 7S and 19S fractions of hemolysin, and a 3rd slight peak (tubes 24-30) corresponded to the $7 \mathrm{~S}$ region. A slight rise in $\mathrm{OD}$ was also noted in the albumin region.

It is not yet known which protein bands separated by polyacrylamide gel disc electrophoresis ${ }^{2}$ correspond to the peaks obtained by Sephadex gel filtration. However, we now have some idea of the Mw of the proteins in honey bee hemolymph.

Zusammenfassung. Proteine von Bienenhaemolymphe und Kaninchenhaemolysin wurden nach Trennung an Sephadex G-200 verglichen. Aufgrund der bekannten Molekulargewichte der Haemolysinproteine konnten Anhaltspunkte für das Molekulargewicht der Haemolymphproteine gefunden werden.

Martha Gilliam 12

US Department of Agricultuve, Agricultural Research Service, Entomology Research Division, 2000 E. Allen Road, Tucson (Arizona 85719, USA), 14 September 1971.

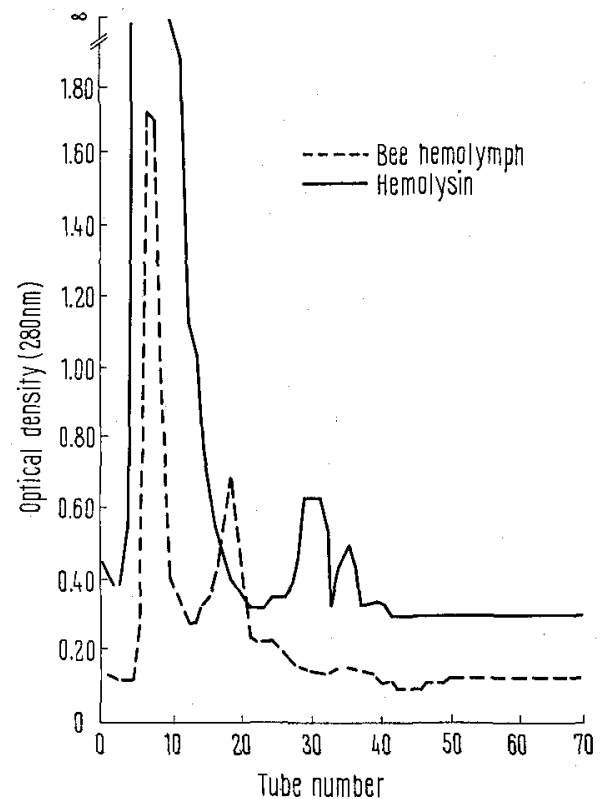

Fractionation of hemolysin and honey bee hemolymph on Sephadex G-200.
${ }^{1}$ M. Gilliam and W. S. Jeter, J. Invertebr. Path. 16, 69 (1970).

${ }^{2}$ M. GilliAM and K. K. JACKsON, in press.

${ }^{3}$ P. Stelos, J. Immun. 77, 396 (1957).

${ }^{4}$ D. W. Talmage, G. G. Freter and W. H. Taliaferro, J. infect. Dis. 98,300 (1956).

${ }^{5}$ Mention of a proprietary product or company name in this paper does not constitute an endorsement of this product by the USDA.

${ }^{6}$ P. Flodkin and J. Killander, Biochim. biophys. Acta 63, 403 (1962).

${ }^{3}$ Sephadex ${ }^{(B)}$-Gel Filtration in Theory and Practice (Pharmacia Fine Chemicals, Sweden 1966).

8 A. A. Nowotny, Basic Exercises in Immunochemistry (SpringerVerlag, Heidelberg 1969), p. 6.

9 R. A. Phelps and F. W. Putnam, in The Plasma Proteins (Ed. F. W. Putnam; Academic Press, New York 1960), vol. 1, p. 171.

10 P. A. Charlwood, Biochem. biophys. Acta 32, 283 (1959).

11 D.H. Campbell, J.S. Garvey, N.E. Cremer and D. H. Sussdorf, Methods in Immunology (W. A. Benjamin, New York 1964), p. 101 and 172.

12 This study was financed in part by Cooperative Agreement Grant No. 12-14-100-9062(33) from the Entomology Research Division of the USDA and was done in cooperation with the Arizona Agricultural Experiment Station, Tucson. 